V.Ya. Halchenko, Yu.Yu. Bondarenko, S.A. Filimonov, N.V. Filimonova

\title{
DETERMINATION OF INFLUENCE OF GEOMETRIC PARAMETERS OF PIEZOCERAMIC PLATE ON AMPLITUDE CHARACTERISTICS OF LINEAR PIEZOMOTOR
}

\begin{abstract}
Purpose. The purpose of the paper is to determine the influence of the geometric parameters of the stator of a linear piezoceramic motor in the form of a piezoceramic plate on the characteristics of its amplitude oscillations. Methodology. For the research, mathematical modeling in the COMSOL Multiphysics software package was used, taking into account the interrelation of electrostatic and mechanical phenomena. Results. By numerical simulation of the process of operating of a linear piezoceramic motor, a rational ratio of the width to the length of the piezoceramic plate is determined. Originality. The rational value of the thickness $h$ of the piezoceramic plate of the motor is also established. Approximate dependencies are proposed for determining the parameters of the relationship between the geometric dimensions of the piezoceramic plate of a linear piezomotor, which makes it possible to predict its characteristics. The adequacy of calculation models is confirmed by experimental studies. Practical value. The results obtained can be used in the design of piezoceramic motors. References 15 , figures 8 .

Key words: piezoceramics, piezoceramic motor, piezoceramic plate.
\end{abstract}

Метою статті є визначення впливу геометричних параметрів статора лінійного п'єзокерамічного двигуна у вигляді п'єзокерамічної пластини на характеристики ї̈ амплітудних коливань. Для проведення досліджень використовувалося математичне моделювання в середовищі пакета програм COMSOL Multiphysics 3 урахуванням взаємозв'язку електростатичних $і$ механічних явищ. Шляхом чисельного моделювання процесу функціонування лінійного п'єзокерамічного двигуна визначено раціональне відночення иирини до довжини п'єзокерамічної пластини. Встановлено також раціональне значення товщини $h$ n'єзокерамічної пластини двигуна. Запропоновані апроксимаційні залежності для визначення параметрів зб'язку мізс геометричними розмірами п'єзокерамічної пластини лінійного п'єзодвигуна, щңо дозволяе прогнозувати його характеристики. Адекватність модельних розрахунків підтверджена експериментальними дослідженнями. Отримані результати можуть використовуватися при проектуванні п'єзокерамічних двигунів. Бібл. 15 , рис. 8.

Ключові слова: п'єзокераміка, п'єзокерамічний двигун, п'єзокерамічна пластина.

Целью статьи является определение влияния геометрических параметров статора линейного пьезокерамического двигателя в виде пьезокерамической пластины на характеристики ее амплитудных колебаний. Для проведения исследований использовалось математическое моделирование в среде пакета программ COMSOL Multiphysics c учетом взаимосвязи электростатических и механических явлений. Путем численного моделирования процесса функционирования линейного пьезокерамического двигателя определено рациональное отношение ширины к длине пьезокерамической пластины. Установлено такэке рациональное значение толщины һ пьезокерамической пластины двигателя. Предложены аппроксимационные зависимости для определения параметров связи мељду геометрическими размерами пьезокерамической пластины линейного пьезодвигателя, что позволяет прогнозировать его характеристики. Адекватность модельных расчетов подтверэждена экспериментальными исследованиями. Полученные результаты могут использоваться при проектировании пьезокерамических двигателей. Библ. 15 , рис. 8. Ключевые слова: пьезокерамика, пьезокерамический двигатель, пьезокерамическая пластина.

Introduction. Piezoelectric motors are used in microscopy, robotics, photographic equipment, nanometrology, nanolithography, nanoprint, microdosing, etc. They can be used for vacuum and cryogenic equipment, as well as ultra-precise positioning of objects and systems, in particular, for radar systems [1-3].

Piezomotors are devices in which mechanical movement is achieved due to the inverse piezoelectric effect. The materials that form the basis of such drives are called piezoelectrics. The inverse piezoelectric effect consists in changing the linear dimensions of a piezoelectric when an electric field is applied to it.

The relevance of the use of piezoelectric motors in various precision measuring and tracking systems, the adjustable values of which are angular and linear displacements, is explained by several factors. This is, first of all, their high resolution (up to $0.1 \mathrm{~nm}$ ), the possibility of self-stopping of the drive link, the maximum duration of trouble-free operation, as well as their high reliability [3]. A demonstration application based on piezomotors is a theodolite [4], which is an exact instrument on which a movable telescope is mounted for measuring angles in the horizontal and vertical planes.

Piezoelectric motors have a number of advantages over electromagnetic ones, namely [2]: the absence of radiated magnetic fields and their resistance to their influence; the possibility of miniaturization; wide range of rotational speeds and torques on the shaft; fire resistance; absence of windings; simple manufacturing technology and, consequently, higher efficiency.

At the same time, behind the external design simplicity of a piezoelectric motor, there is a whole series of physical phenomena that are interconnected in a complex way $[5,6]$. The difficulties of their joint accounting significantly restrain the development and improvement of this type of motors.

The object of the research is the interaction processes of transverse bending and longitudinal mechanical oscillations of the stator of a linear piezoceramic motor. The subject of the research is

(C) V.Ya. Halchenko, Yu.Yu. Bondarenko, S.A. Filimonov, N.V. Filimonova 
the piezoelectric element of a linear piezoceramic motor, i.e. stator.

The goal of the work is determination of the influence of the geometric parameters of a piezoceramic plate of a linear piezoceramic motor on the characteristics of its amplitude oscillations.

Problem definition. To achieve this goal, it is necessary to consistently solve a number of problems: determine the resonance frequency at which the piezoceramic element, namely, the stator pusher, becomes elliptical oscillations; determine the maximum amplitude of oscillations of the pusher when changing the geometry (width and length) of the piezoceramic plate; determine the rational ratio of the width to the length of the piezoceramic plate and the rational thickness of the piezoceramic plate with the selected effective ratio of its width to length.

Literature review. Piezoelectric motors according to the principle of the final movement of the rotor (carriage) can be classified into linear and rotational types. This paper discusses a linear piezoelectric motor. One of the most common types of linear piezoelectric motors is the design shown in Fig. 1 [4, 7-9]. The main elements of this piezoelectric motor are: rectangular monolithic piezoceramic plate (stator) 1 with electrodes 2 , 3 ; friction tip (pusher) 4 , as well as a carriage (rotor, which is not shown in the Figure). Electrode 2 is divided into two sections $-5,6$. The pusher and the plate are a one-piece construction made of a piezoceramic material. Piezoceramic plate from side 7 under the action of an external force $F$ is pressed against the carriage (rotor).

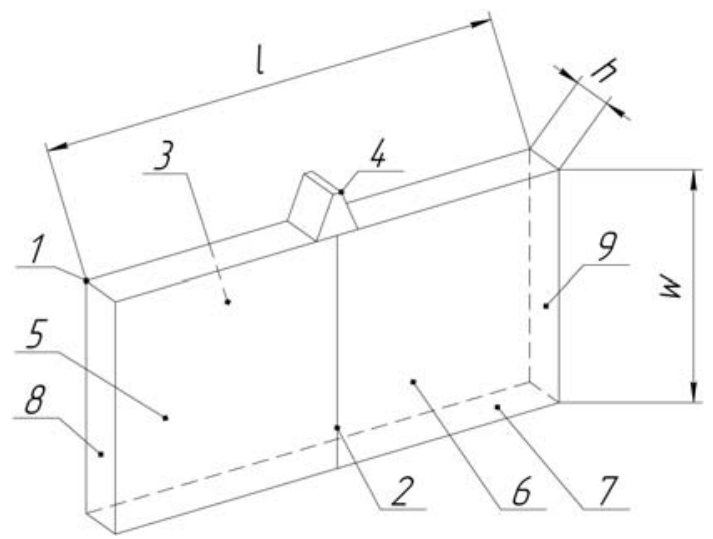

Fig. 1. Piezoceramic plate of a linear piezoceramic motor of the Company Physik Instrumente

The piezoelectric motor operates as follows (Fig. 1). The control voltage is applied to one of the sections 5 or 6 of the electrode 2 , which depends on the chosen direction of movement of the carriage, and to the opposite electrode 3 , which is common («ground»). In this design of a piezoelectric motor, in order to obtain a linear movement of the carriage, in the pusher oscillations are excited in two mutually perpendicular directions. In this case, the longitudinal vibrations in the pusher are excited by the longitudinal oscillations of the piezoplate (stator), and the transverse bending vibrations - by mechanical way, due to the interaction of the pusher with the surface of the carriage. Thus, the pusher begins to perform oscillations in the shape of an ellipse and push the carriage.
One of the main criteria for designing such a linear piezoelectric motor is the complex matching of the geometric parameters of a piezoceramic plate, namely, length, width and thickness, for maximum energy transfer to its carriage [10]. Incorrect selection of these parameters significantly affects the technical characteristics of the linear piezoceramic motors.

In the works $[11,12]$ the description of this design of a piezoceramic motor is given, and they say about «a certain ratio of length to width of the selected element».

In the works [5, 7-9], only one of the possible ratios of width to plate length is given, at which acceptable results can be obtained is presented. In this case, the dependence on the change in its thickness is not given. At the same time, it is not known whether such a choice is close to optimal.

Theoretically, there are other ratios of width to length of the piezoelectric element, at which the maximum oscillations or close to them are reached.

Analysis of technical literature, research papers, and patents showed that in the existing works the choice of parameters is not considered, and also the dependencies for the geometry of the piezoceramic plate of a linear piezoceramic motor, providing an effective mode of operation, are not presented.

Thus, the determination of rational parameters of a piezoceramic plate of a linear piezoceramic motor is an important and urgent task.

Materials and methods. Mathematical dependencies are known for calculating piezoceramic elements of standard shapes (plate, disk, ring, bar and rod) without small structural details on them [13].

The parameters of the piezoceramic plate (static shift along the length $\Delta l$, width $\Delta w$ and thickness $\Delta h$ ) can be determined using the empirical formulas below [13]:

$$
\begin{aligned}
& \Delta l=\frac{d_{31} \cdot V_{l}}{h} ; \\
& \Delta w=\frac{d_{31} \cdot V_{w}}{h} ; \\
& \Delta h=d_{33} \cdot V ;
\end{aligned}
$$

where $\Delta l$ is the static shift in length, $\Delta w$ is the static shift in width, $\Delta h$ is the static shift in thickness, $d_{31}$ and $d_{33}$ are the piezoelectric modules, $h$ is the thickness of the piezoceramic plate, $V_{l}, V_{w}$ and $V$ is the applied voltage to the corresponding side of the plate (length, width and thickness).

At the same time, the use of elementary methods of calculation does not allow visualizing the shape of oscillation of the entire piezoceramic element, and therefore does not make it possible to determine the acceptable shape of its oscillations.

Considering the technical features of piezoelectric motors, which make it difficult to experimentally determine and select the correct oscillation shape of the piezoelectric element, it is optimal to use for this purpose numerical calculation methods implemented by specialized CAD systems.

To study the influence of the design parameters of the piezoceramic plate of a linear piezoelectric motor, numerical simulation of the operation of the piezoelectric element was carried out using the COMSOL Multiphysics 3.5 software package. 
The COMSOL piezoelectric device interface combines the functionality of modeling of solid mechanics modules and electrostatics COMSOL's Solid Mechanics and Electrostatics into one tool for modeling piezoelectric materials. Piezoelectric devices in COMSOL Multiphysics 3.5 are simulated using the Piezoelectric Effects module. Since the operation of piezoelectric motors is based on the reverse piezoelectric effect, therefore, the Stress-Charge Form mode is selected in the Piezoelectric Effects module.

The piezoelectric element is characterized by the connection between the deformation and the electric field, which is determined by the material or constitutive relations [13]:

$$
T=c_{E} S-e^{T} E ; \quad D=e S-\varepsilon_{S} E ;
$$

where $S$ is the deformation, $T$ is the mechanical stress, $E$ is the electric field strength, $D$ is the electric displacement.

The material parameters $c_{E}, e$ and $\varepsilon_{S}$ in (2) correspond to the stiffness of the material, the coefficient of electromechanical coupling and the dielectric permeability. These values are of the 4 th, the $3 \mathrm{rd}$ and the 2nd rank tensors, respectively, but since tensors are symmetric for physical reasons, they can be represented as matrices in an reduced notation, which is usually more convenient [14].

For modeling, Lagrangian finite elements with elementary second order basis functions, LagrangeQuadratic, were used.

The linear piezoceramic motor was analyzed in the Frequency response mode. The calculated finite element mesh in the «Mesh» section is selected as orthogonalized - Normal. The investigated 3D model is represented by a set of elements obtained as a result of meshing with a tetragonal dividing. Direct is used as a solver, in which the SPOOLES numerical method is chosen to solve systems of linear equations with sparse matrices.

The material used for modeling a piezoceramic plate was a brand of piezoceramic PZT-5H. Variants of the geometry of the piezoceramic plate are represented by the parameters $K=w / l$ in dimensionless form, obtained by the ratios of width $w$ to its length $l$.

At the first stage of modeling, the parameter $K$ changed from 0.125 to 1.25 with a step of 0.125 , while the thickness remained constant at $3 \mathrm{~mm}$. At this stage, a rational relationship was determined between the length and width of the piezoceramic plate. At the second stage of the simulation, with the chosen ratio of the parameter $K$, the thickness of the piezoceramic plate was changed from 1 to $6 \mathrm{~mm}$ with a step of $1 \mathrm{~mm}$. The geometrical dimensions of the pusher did not change (Fig. 2).

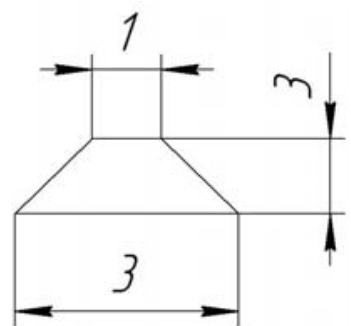

Fig. 2. Linear piezoelectric motor pusher dimensions
The boundary conditions for the model of a piezoelectric motor are as follows: piezoceramic plate 1 in width on both sides 8,9 (Fig. 1) has the type of boundary conditions Roller; electrical voltage (Electric potential) of $100 \mathrm{~V}$ is applied to the partitioned electrode 5 , and the ground (Ground) to the entire electrode 3 on the opposite side.

When conducting numerical simulations in the COMSOL Multiphysics software package, the resonance frequency was first determined at which the piezoceramic element, namely the plunger, acquires elliptical oscillations. The dynamics of elliptical movements of the piezoelectric motor pusher is quite complex and is provided by resonant phenomena, which is described in detail in [3]. Important for their implementation is the provision of the resonance mode, which is fixed at stepwise variation of the control voltage frequency and manifests itself in a sharp increase in amplitude periodic oscillations of the piezoelectric element sizes at one of the model frequencies. Approximate resonant frequency approximately without taking into account the influence of the pusher can be determined using the recommendations [15]. In the vicinity of this frequency with a step of $100 \mathrm{~Hz}$, numerical experiments were conducted using the COMSOL software package to determine its exact value. Then, when the geometrical dimensions of the piezoceramic plate were changed, the maximum amplitude of the oscillation of the pusher was determined, and the rational ratio of the width to the length of the piezoceramic plate was selected. Finally, studies were conducted on the choice of a rational thickness of a piezoceramic plate.

Experimental studies were conducted to verify the adequacy of the results obtained by numerical simulation. Fig. 3 shows a schematic representation of an experimental linear piezoelectric motor.

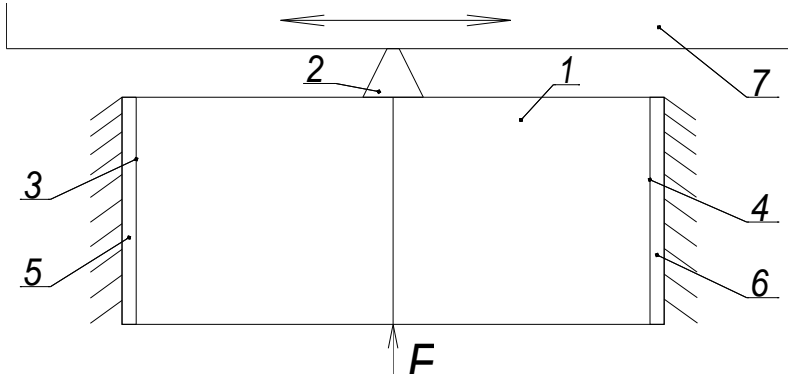

Fig. 3. Schematic representation of an experimental linear piezoelectric motor

The methodology of the experiments is as follows. The piezoelectric plate 1 with the hub 2 is fixed so that it is fixed from opposite sides by width 3,4 across damping rubber gaskets 5,6 . The hub 2 of the piezoelectric plate 1 is firmly pressed against the rolling guide (carriage) 7 by the pressing force $F$ acting from the opposite side and created by a leaf spring. The pressing force can be changed using adjustment screws.

Results of investigations. Some of the results of numerical simulation of oscillations of a piezoceramic plate of a linear motor are presented in Fig. 4, which 
illustrates the oscillations of a piezoceramic plate of the motor. In Fig. 4, 6, on the right, on the vertical axis, the color scale of the gradation of the amplitude of oscillations of the geometric dimensions of a piezoplate is shown. The values of the resonant frequency of oscillations are taken based on the graphical images of the conducted numerical studies in the COMSOL Multiphysics environment in the pusher region. The numerical values of the frequency are displayed in the

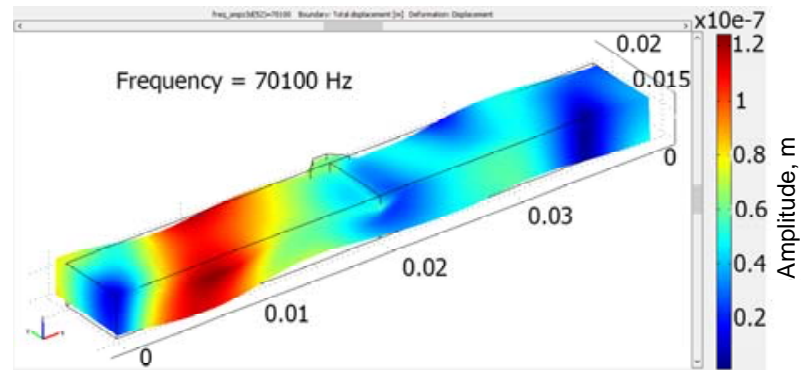

$a$

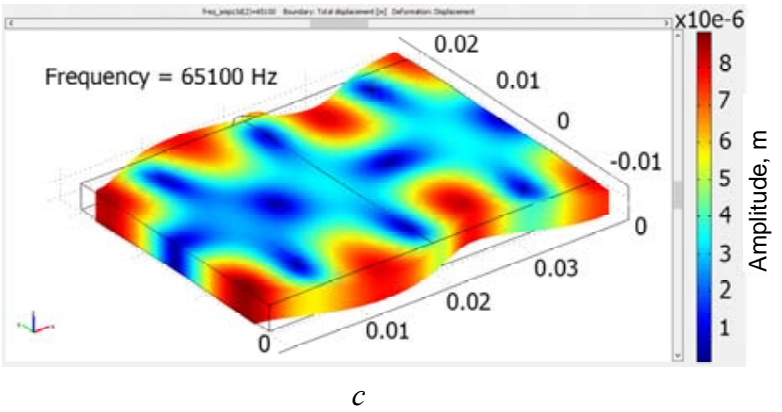

postprocessor window of the package automatically and correspond to the maximum amplitude of the piezoplate oscillations. Thus, we obtain a set of frequencies taken for various ratios of the geometric parameters of the piezoceramic plate. For example, the frequency $f_{\text {theor }}=74.9 \mathrm{kHz}$ is obtained with the following plate sizes: $l=40 \mathrm{~mm} ; w=20 \mathrm{~mm} ; h=3 \mathrm{~mm}$. When modeling the size of the piezoceramic plate was changed in the range $w=10 \div 60 \mathrm{~mm}, l=10 \div 60 \mathrm{~mm}$.
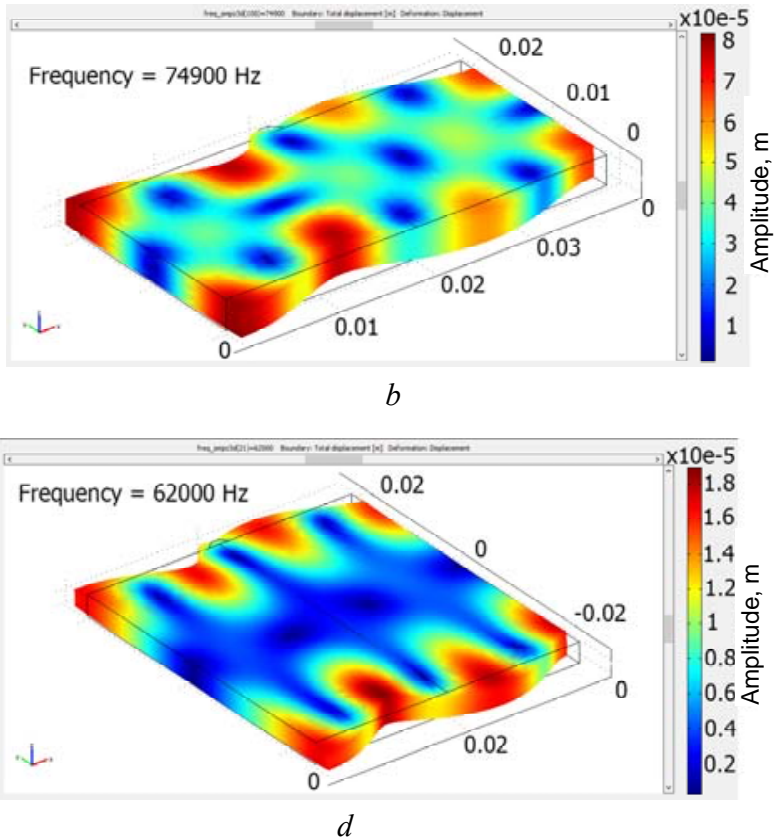

Fig. 4. Some of the results of simulation of amplitude oscillations of a piezoelectric element of a linear motor with different ratios of width to plate length: $a-K=0.125 ; b-K=0.5 ; c-K=0.875 ; d-K=1.125$

As a result of the simulation, resonant frequencies were determined that correspond to the elliptical shape of the pusher oscillation are determined.

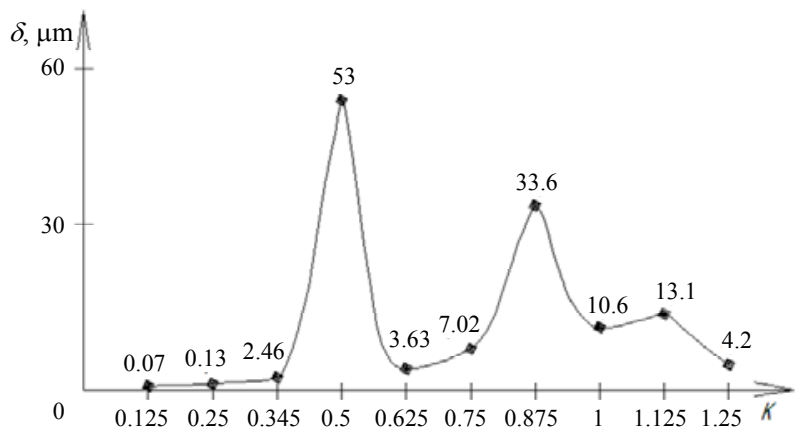

Fig. 5. The dependence of the amplitude of oscillations of the pusher on parameter $K$ of a piezoceramic plate

The obtained results of numerical simulation are presented in graphical form by the dependence of the amplitude of oscillations of the pusher on the parameter $K$ of the piezoceramic plate and are shown in Fig. 5.

As can be seen from the graphs, two ratios can be selected at which the maximum amplitude of the pusher is reached, namely, $53 \mu \mathrm{m}$ for $K=0.5$, and also $33.6 \mu \mathrm{m}$ for $K=0.875$.
The graphical dependence for the amplitude of oscillations of the pusher obtained as a result of numerical simulation was approximated using the least-squares method by a second-order polynomial function

$$
\delta=\frac{1}{a+b x+c x^{2}},
$$

where $\delta$ is the pusher oscillation amplitude, $x$ is the parameter $K$ of the piezoelectric plate, $a=4.074768$, $b=-16.243571, c=16.263542, d=1206.5824$ are the coefficients.

This model is adequate in the range of variation of parameter $K$ of a piezoelectric plate from 0.345 to 0.625 .

After choosing the geometry of the piezoceramic plate, its rational thickness was determined. To do this, during modeling this parameter varied in the range from 1 to $6 \mathrm{~mm}$ with a step of $1 \mathrm{~mm}$.

Some of the results of numerical simulation of oscillations of a piezoceramic plate of a linear motor are presented in Fig. 6.

The results obtained are graphically shown in Fig. 7.

It is obvious that the rational thickness of the piezoceramic plate is $3 \mathrm{~mm}$, while the amplitude of oscillations of the pusher was $53 \mu \mathrm{m}$, which follows from the analysis of the graphical dependencies shown in Fig. 5, 7. 


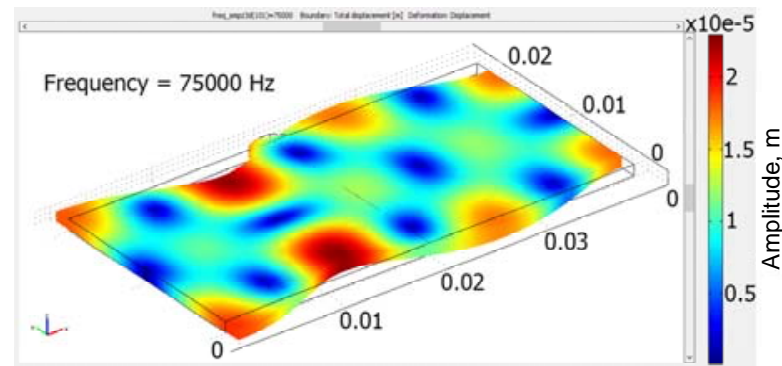

$a$

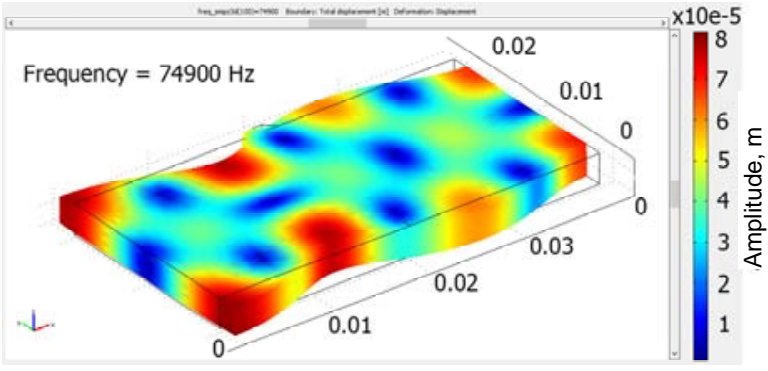

$c$

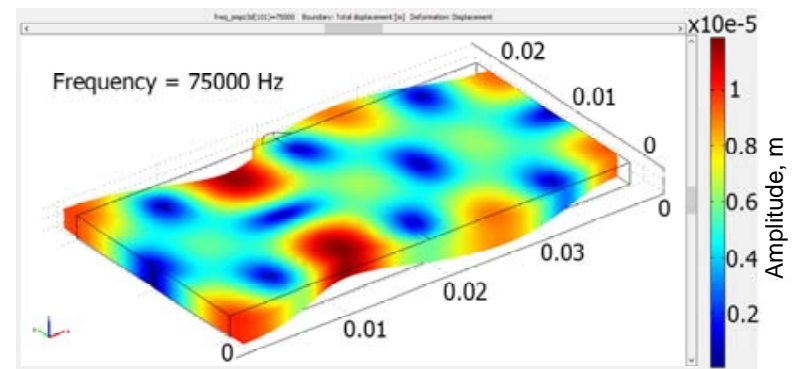

$b$

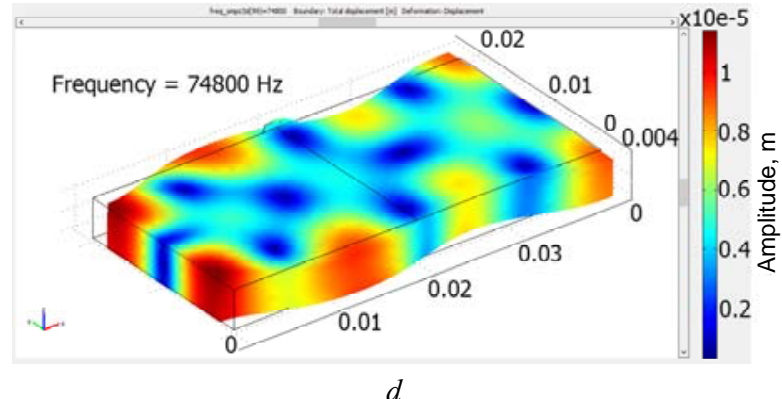

$d$

Fig. 6. Some of the results of simulation of amplitude oscillations of a piezoplate of a linear motor with different thickness at constant parameter: $K=0.5: a-h=1 ; b-h=2 ; c-h=3 ; d-h=4$

The dependence presented in this Figure was approximated by the Gauss function, which has the form:

$$
\delta=a e^{\frac{-(h-b)^{2}}{2 c^{2}}},
$$

where $\delta$ is the pusher oscillation amplitude, $h$ is the piezoelectric plate thickness, $a=53.247361, b=$ $=2.9480015, c=0.50561783$ are the coefficients.

This model is adequate in the range of variation of the piezoceramic plate thickness from 2 to $4 \mathrm{~mm}$.

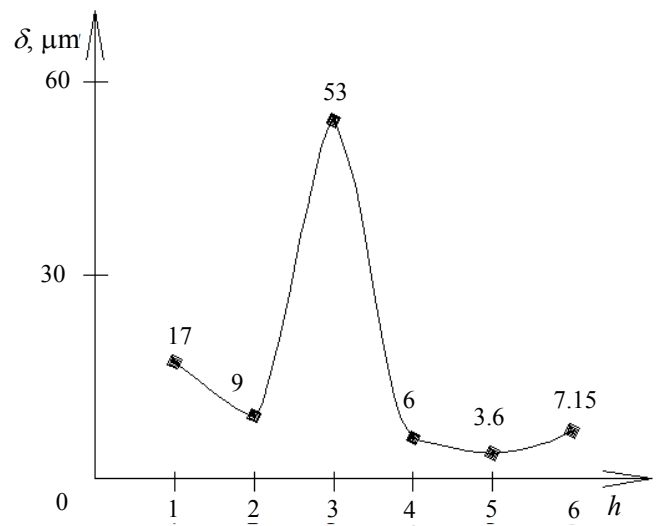

Fig. 7. The dependence of the amplitude of oscillations of the pusher on the piezoceramic plate thickness $h$ at the parameter $K=0.5=$ const

To choose rational sizes of a piezoceramic plate, it is advisable to use graphic (Fig. 5, 7) and analytical (3), (4) dependencies. Guided by the graphs for the maximum amplitude of the pusher, you can choose a rational ratio of the parameters $K$ and thickness $h$. If necessary, in the absence of piezoelectric ceramics of necessary sizes, the choice of rational sizes of $K$ and $h$ can be made using analytical dependencies. In this case, the oscillation amplitude of the pusher is chosen as close to the maximum.
According to the selected rational sizes of the piezoceramic plate, which amounted to $l=40 \mathrm{~mm} ; w=$ $=20 \mathrm{~mm} ; h=3 \mathrm{~mm}$, an experimental sample of a linear piezoceramic motor was made (Fig. 8). The study of its operation in accordance with the previously described method has confirmed the adequacy of determining the resonant frequency and the performance of the motor. The experimentally determined resonant frequency was $f_{\text {exp }}=$ $=77.2 \mathrm{kHz}$, which coincides with the theoretically determined $\left(f_{\text {theor }}=74.9 \mathrm{kHz}\right)$ using the COMSOL Multiphysics software package (Fig. 4,b and Fig. 6,c) with acceptable accuracy not exceeding $3 \%$.

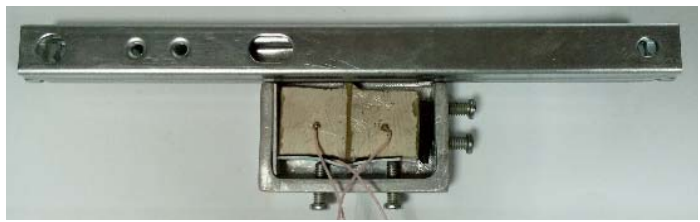

Fig. 8. Experimental sample of linear piezoceramic motor

\section{Conclusions.}

1. By numerical modeling of the operation of a linear piezoceramic motor, the influence of the geometric parameters of the motor piezoelectric element on its amplitude characteristics was determined, graphic and analytical dependencies were established to select their rational ratios.

2. The results of investigations can be used in the design of piezoceramic linear motors.

\section{REFERENCES}

1. Sharapov V. Piezoceramic sensors. Heidelberg, Dordrecht, London, New York, Springer Verlag, 2011. 498 p. doi: 10.1007/978-3-642-15311-2.

2. Panich A.E., Zhukov S.N. P'ezoelektricheskoe priborostroenie. T.4. P'ezoelektricheskie aktuatory [Piezoelectric instrument making. T.4. Piezoelectric actuators]. Rostov-on-Don, TsVVR Publ., 2008. 159p. (Rus). 
3. Petrenko S.F. P'ezoelektricheskii dvigatel' [Piezoelectric motor]. Kiev, Korniichuk Publ., 2002. 96 p. (Rus).

4. Theodolite.

Available at: https://en.wikipedia.org/wiki/Theodolite (accessed on 13 July 2018).

5. Smirnov A.B. Mekhatronika i robototekhnika. Sistemy mikroperemeshchenii $s$ p'ezoelektricheskimi privodami [Mechatronics and Robotics. Micro-movement systems with piezoelectric drives]. St. Petersburg, SPbGPU Publ., 2003. 160 p. (Rus).

6. Khmelev V.N. Istochniki ul'trazvukovogo vozdeistviya. Osobennosti postroeniya $i$ konstruktsii [Sources of ultrasonic action. Features of construction and construction]. Biisk, AGTU Publ., 2013. 196 p. (Rus).

7. Spanner K., Wishnewskiy O., Vyshnevskyy W. New Linear Ultrasonic Micro motors for Precision Mechatronic Systems. In Proceedings of the 10th International Conference on New Actuators. Bremen, Germany. 14-16 June 2006, pp. 439-443.

8. Yokoyama K., Tamura H., Masuda K., Takano T. SinglePhase Drive Ultrasonic Linear Motor Using a Linked Twin Square Plate Vibrator. Japanese Journal of Applied Physics, 2013, vol.52, no.7S, p. 07HE03. doi: 10.7567/jjap.52.07he03.

9. Vyshnevsky O., Kovalev S., Wischnewskiy W. A novel, single-mode piezoceramic plate actuator for ultrasonic linear motors. IEEE Transactions on Ultrasonics, Ferroelectrics and Frequency Control, 2005, vol.52, no.11, pp. 2047-2053. doi: 10.1109/tuffc.2005.1561674.

10. Petrenko S.F., Filimonov S.A., Filimonova N.V., Batrachenko A.V., Lavdanskii A.A. Linear piezoelectric motor based on circular cylindrical plate. Bulletin of Cherkasy State Technological University. Series: Technical sciences, 2014, no.2, pp. 48-52. (Rus).

11. Spanner K., Koc B. Piezoelectric Motors, an Overview. Actuators, 2016, vol.5, no.1, p. 6. doi: 10.3390/act5010006.
12. Shafik A., Ben Mrad R. Piezoelectric Motor Technology: A Review. Nanopositioning Technologies, 2016, pp. 33-59. doi: 10.1007/978-3-319-23853-1 2.

13. Zhukov S.N. Piezoelektricheskaya keramika: printsipy $i$ primenenie [Piezoelectric ceramics: principles and applications]. Minsk, OOO FUAuinform Publ., 2003. 112 p. (Rus).

14. Spicci L., Cati M. Ultrasound Piezo-Disk Transducer Model for Material Parameter Optimization. Excerpt from the Proceedings of the COMSOL Conference, Paris 2010. Available at:

https://uk.comsol.com/paper/download/63120/spicci_paper.pdf (accessed on 20 May 2018).

15. Maslennikova S., Sitnikov A., Mironova I. Calculating the Ultra-Sound Engine Piezoelectric Element Characteristics. Radiooptics Scientific Journal, 2016, vol.16, no.04, pp. 25-40. doi: $10.7463 /$ rdopt.0416.0847731.

Received 13.07.2018

V.Ya. Halchenko ${ }^{1}$, Doctor of Technical Science, Professor, Yu. Yu. Bondarenko ${ }^{1}$, Candidate of Technical Science, Associate Professor,

S.A. Filimonov ${ }^{1}$, Candidate of Technical Science, Associate Professor,

N.V. Filimonova ${ }^{1}$, Candidate of Technical Science,

${ }^{1}$ Cherkasy State Technological University, 460, Shevchenko Blvd., Cherkasy, 18006, Ukraine, phone +380472710092 ,

e-mail: halchvl@gmail.com,s.filimonov@chdtu.edu.ua

How to cite this article:

Halchenko V.Ya., Bondarenko Yu.Yu., Filimonov S.A., Filimonova N.V. Determination of influence of geometric parameters of piezoceramic plate on amplitude characteristics of linear piezomotor. Electrical engineering \& electromechanics, 2019, no.1, pp. 17-22. doi: 10.20998/2074-272X.2019.1.03. 